\title{
Evaluation of Thymol as Biofumigant for Control of Bacterial Wilt of Tomato Under Field Conditions
}

\author{
P. Ji, M. T. Momol, S. M. Olson, and P. M. Pradhanang, North Florida Research and Education Center, University \\ of Florida, IFAS, 155 Research Road, Quincy 32351; and J. B. Jones, Plant Pathology Department, 2253 Fifield \\ Hall, University of Florida, IFAS, Gainesville 32611
}

\begin{abstract}
Ji, P., Momol, M. T., Olson, S. M., Pradhanang, P. M., and Jones, J. B. 2005. Evaluation of thymol as biofumigant for control of bacterial wilt of tomato under field conditions. Plant Dis. 89:497-500.

Volatile plant essential oils thymol and palmarosa oil, used at a concentration of $0.7 \%$, were evaluated under field conditions for control of bacterial wilt of tomato caused by Ralstonia solanacearum. The experimental fields were artificially infested with the bacterial pathogen. Two hours after infestation, the plant essential oils were applied, then the plots were sealed with plastic mulch for 3 or 6 days. Tomato seedlings were transplanted into the field 7 days later. In fall of $2002,92.5 \%$ of tomato plants (cv. Equinox) wilted in the untreated control plots. Both thymol and palmarosa oil soil treatments reduced bacterial wilt incidence significantly. Thymol was more effective than palmarosa oil based on the final assessment, when 33.1 and $48.1 \%$ of the plants had wilted in plots treated with thymol and palmarosa oil, respectively. Soil treatment with either thymol or palmarosa oil produced significantly higher yield of tomato than the untreated control. In 2003, only thymol was evaluated. Thymol application significantly reduced bacterial wilt incidence on the susceptible cultivar Solar Set. Disease incidence in untreated plots reached $65.5 \%$, while in thymol treated plots only $12 \%$ of plants wilted. Thymol treatment also increased yield of Solar Set significantly compared with the untreated control. This is the first report on the use of thymol for controlling a plant disease under field conditions, which indicated that this compound provided effective control of bacterial wilt on susceptible tomato cultivars when used as preplant treatment of soils. Because of its volatile property and broadspectrum functions, thymol shows potential to be used as a soil biofumigant for the management of various plant pathogens.
\end{abstract}

Additional keywords: biorational alternative, soil fumigation

Bacterial wilt caused by Ralstonia solanacearum is a serious disease and a major constraint in the production of tomatoes and many other crops in tropical, subtropical, and warm temperate regions of the world $(3,12,16)$. Infected tomato plants may be stunted or completely wilted, resulting in poor fruit quality such as small fruit size and significant yield loss. In Florida, this disease was first identified in tomato in 1897 , and it occurs commonly in field-grown tomatoes almost throughout the state (17). This bacterial pathogen also occurs worldwide and has a very extensive host range, including hundreds of plant species, which contributes to its recognition as one of the most important bacterial diseases of plants $(3,12)$.

Bacterial wilt is among the most difficult diseases to control (17), and the efficacy of current strategies for management

Corresponding author: Pingsheng Ji

E-mail: pji@ifas.ufl.edu

Accepted for publication 7 January 2005.

DOI: 10.1094/PD-89-0497

(C) 2005 The American Phytopathological Society of this disease is limited. No conventional pesticides are known to provide effective control of this soilborne pathogen. Soil treatments with traditional general-purpose fumigants such as methyl bromide did not provide satisfactory control of the disease $(5,8)$. Control of bacterial wilt in infested soils is very difficult. It is generally considered that crop rotation with a nonhost crop is of minimal value because of the wide range of crop and weed hosts of the pathogen $(12,16)$. Some resistant tomato cultivars are available, but they have not been generally accepted by growers and the commercial tomato industry due to poor horticultural quality and the varying levels of disease resistance that resulted from pathogen variation in different locations $(14,17,32)$. Application of acibenzolar-S-methyl, a chemical elicitor that enhances plant resistance, reduced bacterial wilt incidence significantly on moderately resistant tomato cultivars (P. M. Pradhanang, P. Ji, M. T. Momol, S. M. Olson, J. L. Mayfield, and J. B. Jones, unpublished data). However, acibenzolar$S$-methyl did not provide effective protection against bacterial wilt on commercially acceptable tomato cultivars in the presence of relatively high inoculum pressure $(2 ; \mathrm{P}$.
M. Pradhanang, P. Ji, M. T. Momol, S. M. Olson, J. L. Mayfield, and J. B. Jones, unpublished data). The destructive nature of the disease and ineffective disease suppression with current control measures has made development of effective disease control approaches desirable.

It has been demonstrated that some volatile compounds derived from plants, such as thymol and palmarosa oil, provide disease control potential. Thymol and palmarosa oil are antibacterial agents produced by thyme (Thymus spp.) and palmarosa (Cymbopogon martinii) or other medicinal plants and have been widely used as a general antiseptic or additive in cosmetics or the food industry, or in the medical practice, such as for treatment of oral infections in dentistry $(1,20,21,31$, $34,39)$. In agricultural studies, these compounds have broad-spectrum activities against fungi, nematodes, and insects $(4,6,18,26,40)$. The potential of using plant essential oils for managing bacterial plant diseases has not been evaluated prior to our studies. In 1999, we initiated investigation of plant essential oils for managing bacterial wilt in tomato Greenhouse experiments and in vitro studies indicated that thymol and palmarosa oil had significant efficacy against $R$. solanacearum and efficiently reduced populations of this pathogen in soils to an undetectable level $(24,25,30)$. Tomato plants grown in soils treated with thymol or palmarosa oil did not develop wilt symptoms under greenhouse experimental conditions (30).

While thymol and palmarosa oil have shown promise as effective measures in the control of bacterial wilt, it was unknown if their efficacy would be sustained in the long growing season in tomato fields where more complicated soil and cultural conditions exist. Hence, the objective of this study was to determine if plant essential oils could provide effective control of bacterial wilt of tomato under field conditions. Considering their volatile attribute and broad-spectrum activities, successful development of such compounds as biofumigants would not only provide a potent tool for control of bacterial wilt of tomato, but also afford promise of success in our exploiting of multipurpose biorational alternatives to conventional fumigants for the management of other plant diseases. 


\section{MATERIALS AND METHODS}

Field experiments to evaluate efficacy of plant essential oils for managing bacterial wilt of tomato were conducted at the Uniand Education Center located in Quincy. Thymol and palmarosa oil were evaluated in the first experiment, which was in fall 2002. Thymol was selected for further study in 2003 because it was more economical and effective than palmarosa oil for controlling bacterial wilt. Vapor pressures of thymol and palmarosa oil at $20^{\circ} \mathrm{C}$ are 0.04 and $0.02 \mathrm{~mm} \mathrm{Hg}$, respectively, and the boiling point of thymol is 232 to $233^{\circ} \mathrm{C}$ (not found for palmarosa oil).

Field conditions. The experimental fields had been used for growing tomatoes for several years and were naturally infested with $R$. solanacearum (race 1, biovar 1). The soil was an Orangeburg loamy fine sand with a $\mathrm{pH}$ of approximately 6.0. Raised beds were prepared for tomato growth that were $10 \mathrm{~cm}$ high by $91 \mathrm{~cm}$ wide and centered $1.8 \mathrm{~m}$ apart. Beds were fumigated with methyl bromide $(67 \%)$ and chloropicrin $(33 \%)$ at a broadcast equivalent rate of $392 \mathrm{~kg}$ a.i./ha for control of weeds and other soilborne pathogens, fertilized with $218-67-218 \mathrm{~kg} / \mathrm{ha}$ of N-P-K, and covered with polyethylene mulch. A drip irrigation line was established under polyethylene mulch, and the plots were irrigated to field capacity by drip irrigation prior to pathogen inoculation of the soil.

Inoculation of pathogen in the field. $R$. solanacearum tomato strain Rs5 (race 1, biovar 1), isolated in Quincy (29), was used in the studies. Bacterial culture was grown on casamino acid peptone glucose (CPG) agar plates at $28^{\circ} \mathrm{C}$ for $48 \mathrm{~h}$, washed from the plates, and suspended in sterile deionized water. Bacterial suspension was adjusted to approximately $3 \times 10^{7}$ $\mathrm{CFU} / \mathrm{ml}$ using sterile deionized water. A $15-\mathrm{cm}$ application hole was made where tomato plants were going to be transplanted, and a volume of $50 \mathrm{ml}$ of the bacterial suspension was applied to each application hole. versity of Florida North Florida Research

Application of essential oils. A volume of $200 \mathrm{ml}$ of thymol (Sigma-Aldrich Co., St. Louis, MO) or palmarosa oil (Prima Fleur, San Rafael, CA) solution (thymol $1.4 \mathrm{~g}$ or palmarosa oil $1.4 \mathrm{ml}, 70 \%$ ethanol $7 \mathrm{ml}$, water $191.6 \mathrm{ml}$, detergent $200 \mu \mathrm{l}$ ) was applied $2 \mathrm{~h}$ after pathogen inoculation in each hole used for inoculation. For untreated controls, $200 \mathrm{ml}$ of the solution without the essential oils (70\% ethanol 7 $\mathrm{ml}$, water $191.6 \mathrm{ml}$, detergent $200 \mu \mathrm{l}$ ) was used. The holes on plastic mulch were sealed with duct tape after application of the essential oils, and the duct tape was cut open for aeration 3 or 6 days, in 2002 or 2003 field trial, respectively, after oil application.

Tomato plants and experiment design. The susceptible tomato cultivars Equinox and Solar Set were used in the field experiments in 2002 and 2003, respectively. Tomato plants were grown in a greenhouse in Terra-lite agricultural mix (Scott-Sierra Horticultural Products Co., Maryville, $\mathrm{OH}$ ) in expanded polystyrene flats with $3.5 \times$ $3.5 \mathrm{~cm}^{2}$ cells. Five-week-old tomato seedlings were transplanted at $50-\mathrm{cm}$ spacing within a row into raised beds in the field 1 week after essential oil application holes were cut open for aeration. Experimental plots consisted of two rows 5 or $10 \mathrm{~m}$ long with 10 or 20 plants per row in 2002 and 2003, respectively. Buffer zones of $2 \mathrm{~m}$ without tomato seedlings were maintained between plots. Tomato plants were staked, tied over time, and treated by foliar sprays with standard insecticides and fungicides at weekly intervals until harvest. A randomized complete block design was employed, eight replications with 20 plants per treatment in each replication for 2002 and five replications with a total of 200 plants for 2003.

Disease and yield assessment and data analysis. Wilted tomato plants were sampled for bacterial ooze test and isolation of $R$. solanacearum on a semiselective modified SMSA medium $(7,9)$. Presumptive colonies of $R$. solanacearum were confirmed by gas chromatographic profiling of

Table 1. Effect of plant essential oils for bacterial wilt incidence and tomato yield (mean \pm standard error) under field conditions (fall 2002, Quincy, FL)

\begin{tabular}{lcccc}
\hline & \multicolumn{3}{c}{ Plants wilted (\%) $)^{\mathbf{a , b}}$} & $\begin{array}{c}\text { Marketable yield } \\
\text { (kg/ha) }\end{array}$ \\
\cline { 2 - 4 } Treatment $^{\mathbf{c}, \mathbf{b}}$ & $\mathbf{1 9} \mathbf{A u g}$ & $\mathbf{4 ~ S e p t}$ & $\mathbf{1 ~ O c t}$ & \\
\hline Untreated & $61.3 \pm 8.3$ & $88.8 \pm 5.1$ & $92.5 \pm 3.7$ & $2,454.8 \pm 1,843.1$ \\
Thymol & $5.6 \pm 1.5$ & $23.1 \pm 4.1$ & $33.1 \pm 5.3$ & $31,444.8 \pm 2,287.1$ \\
Palmarosa oil & $7.5 \pm 2.1$ & $30.0 \pm 6.1$ & $48.1 \pm 6.1$ & $26,303.1 \pm 2,869.0$ \\
$\quad$ LSD & 14.8 & 15.0 & 14.3 & $6,849.9$ \\
$P>F$ & & & & \\
Untreated vs. thymol & $<0.0001$ & $<0.0001$ & $<0.0001$ & $<0.0001$ \\
Untreated vs. palmarosa oil & $<0.0001$ & $<0.0001$ & $<0.0001$ & $<0.0001$ \\
Thymol vs. palmarosa oil & 0.79 & 0.34 & 0.04 & 0.13 \\
\hline
\end{tabular}

a Mean of eight replications.

b Tomato seedlings were transplanted into the field on 5 August 2002.

${ }^{c}$ Thymol and palmarosa oil were applied at a concentration of $0.7 \% 2 \mathrm{~h}$ after inoculation of the pathogen in the field. Tomato plants (cv. Equinox) were transplanted 10 days after application of the plant essential oils. $\mathrm{LSD}=$ least significant difference.

${ }^{\mathrm{d}}$ Each treatment consisted of eight replications with 20 plants in each replication. whole-cell fatty acid methyl esters (MIDI, Newark, DE), as described previously $(30,36)$. Plants that had completely wilted were counted weekly beginning 1 week after transplanting. Disease incidence was calculated as the percentage of plants that had completely wilted. Tomato fruits were harvested at the end of the season. A total of four harvests were made at weekly intervals. The total marketable yield was recorded in 2002. In 2003, marketable and unmarketable yields were determined and fruits were graded to USDA standards by a fruit and vegetable processing machine (Model No. 1650 Roller, TEW Manufacturing Corp., Penfield, NY) as extra large, large, and medium $(35,37)$. The weight and number of fruits in each category were recorded and the average fruit size was calculated based on the weight and number of fruits in all size categories. Analysis of variance (ANOVA) was used to determine the effect of the treatments on bacterial wilt incidence and tomato yield using the Statistical Analysis System (SAS Institute, Cary, NC). Orthogonal contrasts and least significant difference were used to compare the means.

\section{RESULTS}

Field experiment 2002. Typical bacterial wilt symptoms were observed 1 week after transplanting. The cause of wilt was confirmed to be $R$. solanacearum by looking for bacterial ooze and isolating the bacterium from wilted plants followed by fatty acid analysis of the bacterial culture obtained. The tomato cultivar used, Equinox, was very susceptible to bacterial wilt. Disease incidence progressed rapidly beginning 1 week after transplanting. Final disease incidence reached $92.5 \%$ in plots without application of essential oils, indicating high inoculum pressure (Table 1). Thymol application provided effective protection against bacterial wilt, with only $33.1 \%$ of plants wilted in thymol-treated plots, which was significantly lower than the untreated control (Table 1). Palmarosa oil also reduced bacterial wilt incidence significantly compared with the untreated plots; however, it was less effective than thymol, with approximately half of the plants wilted in palmarosa oil treated plots (Table 1). Both thymol and palmarosa oil treatments significantly protected tomato plants from severe yield loss as a result of the disease. The untreated control plots produced 2,454.8 kilograms of fruit per hectare, while significantly higher tomato yield was produced in palmarosa oil and thymol treated plots, which had 10 or 13 times higher yield, respectively (Table 1).

Field experiment 2003. As occurred with Equinox in the 2002 field experiment, seedlings of susceptible tomato cultivar Solar Set started to show bacterial wilt symptoms 1 week after transplanting into the field. Without thymol treatment, half of the plants wilted 1 month after transplant- 
ing and $65 \%$ of the plants wilted and were dead within 2 months (Table 2). Disease incidence was stabilized 2 months after transplanting until harvest. Application of thymol consistently provided significant protection against bacterial wilt during the whole growing season. Only $0.5 \%$ of plants wilted within 1 month after transplanting when the soil was treated with thymol, and thymol-treated plots reached a maximum of only $12 \%$ disease incidence near the end of the field experiment (Table 2 ). Weight of marketable fruits from thymol-treated plots was 3.6 times higher than from the untreated control (Table 3). The average fruit size and percent fruits that were marketable were also significantly increased following thymol application (Table 3).

\section{DISCUSSION}

Development of effective fumigants for the management of various soilborne plant pathogens has been the subject of increasing interest (22). The bacterial wilt pathogen appears to persist in soils over long periods or survive in soils for extended periods in association with infested plant debris $(11,16,23)$, which provide inoculum sources between crop growing seasons. Hence, preplant soil treatment using adequate fumigants to reduce or eliminate soil populations of the pathogen is an appropriate strategy in the management of this disease. However, studies leading to the identification of effective fumigants for control of bacterial wilt caused by $R$. solanacearum are scarce.

Thymol has been commercially available for treatment of oral infections for more than a century (31) and was shown to inhibit a wide variety of Gram-positive and Gram-negative bacteria in medical and food sciences $(10,13,38,39)$. Modes of action of the antibacterial property of thymol appeared to include disruption of bacterial cell membrane integrity by altering protein reactions $(13,15,38)$. Antibacterial activity of thymol against $R$. solanacearum was shown in in vitro studies (24) when thymol placed in the lid of a petri dish inhibited growth of the bacterium on the agar medium. In previous greenhouse studies, soil treatment with thymol reduced $R$. solanacearum population in the soil to undetectable levels, and tomato seedlings transplanted into thymol-treated soils did not develop symptoms of bacterial wilt, nor could the pathogen be isolated for at least 4 weeks after inoculation (30).

Thymol used for soil treatment before transplanting provided significant and season-long protection against bacterial wilt in repeated field experiments conducted in 2002 and 2003. This result was consistent with our previous findings that thymol provided effective control of bacterial wilt of tomato under greenhouse conditions (30). Soil fumigation with thymol also prevented the dramatic yield loss due to bacterial wilt that occurred in untreated tomatoes; thymol-treated plots produced $41.9 \mathrm{t}$ of tomato fruit per hectare in 2003 (Table 3), which was equivalent to the average yield in this region under normal cultural conditions (27). Palmarosa oil also provided significant disease reduction and increased tomato yield significantly in 2002, but it was not tested in 2003 since it was less economical and effective than thymol in 2002.

Thymol can be synthesized, which greatly reduces the cost of producing it from medicinal plants and makes its practical application feasible. Thymol (99\% pure crystal form) can be purchased at a price of US $\$ 14 / \mathrm{kg}$ (Seema International, New Delhi, India. Purchase online at their website). At a broadcast rate of approximately $73 \mathrm{~kg} / \mathrm{ha}$, thymol can significantly reduce bacterial wilt of tomato when applied through drip irrigation (P. Ji, M. T. Momol, J. R. Rich, S. M. Olson, and J. B.
Jones, unpublished data). This represents a cost of US $\$ 1,022 /$ ha, which is higher than that for methyl bromide and chloropicrin (\$821/ha). However, it is anticipated that agricultural grade thymol (95\% purity or less), when purchased in large quantities, will cost less than $99 \%$ pure; thus thymol should be economically feasible for use in commercial tomato production.

Besides its antibacterial property, thymol has been reported to have fungicidal $(4,19,25,28,40)$, nematicidal $(4,24,26)$, and insecticidal $(18,33)$ activities. Fumigation with thymol has been used for control of postharvest fungal diseases $(19,28)$; however, its efficacy in control of plant pathogenic microorganisms has not been evaluated under natural field conditions. Hence, this study is the first report concerning field evaluation of thymol for plant disease management. With its plant origin, thymol is generally recognized as a safe compound by the U.S. Food and Drug Administration (FDA) and Environmental Protection Agency (EPA), and was exempted from the requirement of a tolerance by EPA for application on edible agricultural products (40 CFR Part 180, 6 June 2003). This property, along with its wide spectrum functions, make this compound promising as an environmentally safe alternative to conventional general-purpose fumigants such as methyl bromide and chloropicrin. Studies are in progress using drip irrigation for thymol application to further evaluate the efficacy of thymol. Certainly, many issues need to be clarified in further studies. For example, dosage and

Table 3. Effect of soil fumigation with thymol on the yield of tomato in bacterial wilt field experiment (fall 2003, Quincy, FL)

\begin{tabular}{lcccc}
\hline & \multicolumn{4}{c}{ Yield and quality of tomato fruits (mean $\pm \mathbf{S E})^{\mathbf{a}, \mathbf{b}}$} \\
\cline { 2 - 5 } Treatment $\mathbf{c}^{\mathbf{c}, \mathbf{d}}$ & $\begin{array}{c}\text { Marketable yield } \\
\mathbf{( k g / h a )}\end{array}$ & $\begin{array}{c}\text { Total no. of } \\
\text { cartons/ha }\end{array}$ & $\begin{array}{c}\text { Marketable fruit } \\
(\boldsymbol{\%})\end{array}$ & $\begin{array}{c}\text { Average fruit } \\
\text { size }(\mathbf{g})\end{array}$ \\
\hline Untreated & $11,641.4 \pm 1,445.9$ & $1,026 \pm 127$ & $70.1 \pm 0.9$ & $125.8 \pm 2.1$ \\
Thymol & $41,899.9 \pm 5,395.7$ & $3,692 \pm 475$ & $75.4 \pm 1.6$ & $136.7 \pm 2.2$ \\
LSD & $14,249.0$ & $1,255.4$ & 5.1 & 10.6 \\
$P>F$ & 0.004 & 0.004 & 0.045 & 0.043 \\
\hline
\end{tabular}

${ }^{a}$ Mean of five replications. SE $=$ standard error of the mean.

${ }^{\mathrm{b}}$ Carton $=11.35 \mathrm{~kg}$ (25 pounds).

${ }^{c}$ Thymol was applied at a concentration of $0.7 \% 2 \mathrm{~h}$ after pathogen inoculation in the field. Tomato plants (cv. Solar Set) were transplanted into the field 13 days after application of thymol. LSD = least significant difference.

${ }^{\mathrm{d}}$ Each treatment consisted of five replications with 40 plants in each replication.

Table 2. Efficacy of thymol as soil fumigant for control of bacterial wilt of tomato under field conditions (fall 2003, Quincy, FL)

\begin{tabular}{|c|c|c|c|c|c|c|}
\hline \multirow[b]{2}{*}{ Treatment $^{\mathrm{c}, \mathrm{d}}$} & \multicolumn{6}{|c|}{ Plants wilted $(\%, \text { mean } \pm \mathrm{SE})^{\mathrm{a}, \mathrm{b}}$} \\
\hline & 14 Aug & 28 Aug & 18 Sept & 2 Oct & 23 Oct & 13 Nov \\
\hline Untreated & $12.5 \pm 1.8$ & $49.0 \pm 2.9$ & $62.0 \pm 4.1$ & $64.5 \pm 3.4$ & $65.5 \pm 3.4$ & $65.5 \pm 3.4$ \\
\hline Thymol & 0 & $0.5 \pm 0.5$ & $3.0 \pm 1.8$ & $11.5 \pm 5.6$ & $12.0 \pm 6.0$ & $12.0 \pm 6.0$ \\
\hline LSD & 4.9 & 8.9 & 14.2 & 19.7 & 20.3 & 20.3 \\
\hline$P>F$ & 0.002 & 0.0001 & 0.0003 & 0.0017 & 0.0019 & 0.0019 \\
\hline
\end{tabular}

${ }^{a}$ Mean of five replications. $\mathrm{SE}=$ standard error of the mean.

b Tomato seedlings were transplanted into the field on 30 July 2003.

${ }^{\mathrm{c}}$ Thymol was applied at a concentration of $0.7 \% 2 \mathrm{~h}$ after pathogen inoculation in the field. Tomato plants (cv. Solar Set) were transplanted into the field 13 days after application of thymol. LSD = least significant difference.

${ }^{\mathrm{d}}$ Each treatment consisted of five replications with 40 plants in each replication. 
methods of application in the field will need to be optimized to achieve maximum disease control efficacy and economic benefit. Use of thymol, resistant tomato cultivars, and other promising compounds such as acibenzolar- $S$-methyl may be integrated to achieve elevated efficacy in control of bacterial wilt. The efficacy of thymol for control of other soilborne plant pathogenic bacteria, fungi, and nematodes can be evaluated under field conditions. These studies will provide a more comprehensive evaluation of the role of thymol as a biofumigant in the production of tomatoes and other crop systems.

\section{ACKNOWLEDGMENTS}

This research was supported by grants from the USDA Southern Region IPM (Jones, Momol, Olson, Grant \# 2002-34103-11934) and T-STAR (Jones, Momol, Olson, Grant \# 2002-34135-12348) programs. We thank Hank Dankers, Laura Ritchie, Jackie Snell, and Seth Wright for their technical assistance. Contribution from the Florida Agricultural Experiment Station (Journal Series R-10201) is appreciated.

\section{LITERATURE CITED}

1. Aeschbach, R., Loliger, J., Scott, B. C., Murcia, A., Butler, J., Halliwell, B., and Aruoma, O. I. 1994. Antioxidant actions of thymol, carvacrol, 6-gingerol, zingerone and hydroxytyrosol. Food Chem. Toxicol. 32:3136.

2. Anith, K. N., Momol, M. T., Kloepper, J. W., Marois, J. J., Olson, S. M., and Jones, J. B. 2004. Efficacy of plant growth-promoting rhizobacteria, acibenzolar-S-methyl, and soil amendment for integrated management of bacterial wilt on tomato. Plant Dis. 88:669-673.

3. Buddenhagen, I., and Kelman, A. 1964. Biological and physiological aspects of bacterial wilt caused by Pseudomonas solanacearum. Annu. Rev. Phytopathol. 2:203-230.

4. Calvet, C., Pinochet, J., Camprubi, A., Estaun, V., and Rodriguez-Kabana, R. 2001. Evaluation of natural chemical compounds against rootlesion and root-knot nematodes and side-effects on the infectivity of arbuscular mycorrhizal fungi. Eur. J. Plant Pathol. 107:601-605.

5. Chellemi, D. O., Olson, S. M., Mitchell, D. J., Secker, I., and McSorley, R. 1997. Adaptation of soil solarization to the integrated management of soilborne pests of tomato under humid conditions. Phytopathology 87:250-258.

6. Delespaul, Q., de Billerbeck, V. G., Roques, C. G., and Michel, O. 2000. The antifungal activity of essential oils as determined by different screening methods. J. Essent. Oil Res. 12:256266.

7. Elphinstone, J. G., Hennessy, J., Wilson, J. K., and Stead, D. E. 1996. Sensitivity of different methods for the detection of Ralstonia solanacearum in potato tuber extracts. EPPO/OEPP Bull. 26:663-678.

8. Enfinger, J. M., McCarter, S. M., and Jaworski, C. A. 1979. Evaluation of chemicals and application methods for control of bacterial wilt of tomato transplants. Phytopathology 69:637-640.
9. Engelbrecht, M. C. 1994. Modification of a semi-selective medium for the isolation and quantification of Pseudomonas solanacearum. ACIAR Bact. Wilt Newsl. 10, 3-5.

10. Evans, J. D., and Martin, S. A. 2000. Effects of thymol on ruminal microorganisms. Curr. Microbiol. 41:336-340.

11. Granada, G. A., and Sequeira, L. 1983. Survival of Pseudomonas solanacearum in soil, rhizosphere, and plant roots. Can. J. Microbiol. 29:433-440.

12. Hayward, A. C. 1991. Biology and epidemiology of bacterial wilt caused by Pseudomonas solanacearum. Annu. Rev. Phytopathol. 29:6587.

13. Helander, I. M., Alakomi, H.-L., Latva-Kala, K., Mattila-Sandholm, T., Pol, I., Smid, E. J., Gorris, L. G. M., and von Wright, A. 1998. Characterization of the action of selected essential oil components on Gram-negative bacteria. J. Agric. Food Chem. 46:3590-3595.

14. Jones, J. B., Jones, J. P., Stall, R. E., and Zitter, T. A. 1991. Compendium of Tomato Diseases. American Phytopathological Society, St. Paul, $\mathrm{MN}$.

15. Juven, B. J., Kanner, J., Schved, F., and Weisslowicz, H. 1994. Factors that interact with the antibacterial action of thyme essential oil and its active constituents. J. Appl. Bacteriol. 76:626-631.

16. Kelman, A. 1953. The bacterial wilt caused by Pseudomonas solanacearum: A literature review and bibliography. North Carolina Agricultural Experiment Station, Tech. Bull. No. 99

17. Kucharek, T. 1998. Bacterial Wilt of Row Crops in Florida. Circ-1207. University of Florida, IFAS, Coop. Ext. Serv.

18. Lee, S., Tsao, R., Peterson, C., and Coats, J. R. 1997. Insecticidal activity of monoterpenoids to western corn rootworm (Coleoptera: Chrysomelidae), twospotted spider mite (Acari: Tetranychidae), and house fly (Diptera: Muscidae). J. Econ. Entomol. 90(4):883-892.

19. Liu, W. T., Chu, C. L., and Zhou, T. 2002. Thymol and acetic acid vapors reduce postharvest brown rot of apricots and plums. HortScience 37:151-156.

20. Mallavarapu, G. R., Rao, B. R. R., Kaul, P. N., Ramesh, S., and Bhattacharya, A. K. 1998. Volatile constituents of the essential oils of the seeds and the herb of palmarosa (Cymbopogon martinii (Roxb.) Wats. var. motia Burk.). Flavour Fragrance J. 13:167-169.

21. Manou, L., Bouillard, L., Devleeschouwer, M. J., and Barel, A. O. 1998. Evaluation of the preservative properties of Thymus vulgaris essential oil in topically applied formulations under a challenge test. Appl. Microbiol. 84:368-376.

22. Martin, F. N. 2003. Development of alternative strategies for management of soilborne pathogens currently controlled with methyl bromide. Annu. Rev. Phytopathol. 41:325-350.

23. McCarter, S. M. 1979. Persistence of Pseudomonas solanacearum in artificially infested soils. Phytopathology 66:998-1000.

24. Momol, M. T., Mitchell, D. J., Rayside, P. A., Olson, S. M., and Momol, E. A. 2000. Plant essential oils as potential bio-fumigants for the management of soilborne pathogens of tomato. (Abstr.) Phytopathology 90:S127.

25. Momol, M. T., Momol, E. A., Dankers, W. A.,
Olson, S. M., Simmons, J. A., and Rich, J. R. 1999. Evaluation of selected plant essential oils for suppression of Ralstonia solanacearum and Meloidogyne arenaria on tomato. (Abstr.) Phytopathology 89: S54.

26. Oka, Y., Nacar, S., Putievsky, E., Ravid, U., Yaniv, Z., and Spiegel, Y. 2000. Nematicidal activity of essential oils and their components against the root-knot nematode. Phytopathology 90:710-715.

27. Olson, S. M., and Simonne, E. H. 2003. Vegetable variety trial results in Florida for 2002 Circ. S-396. University of Florida, IFAS, Coop. Ext. Serv.

28. Paster, N., Menasherov, M., Ravid, U., and Juven, B. 1995. Antifungal activity of oregano and thyme essential oils applied as fumigants against fungi attacking stored grain. J. Food Prot. 58:81-85.

29. Pradhanang, P. M. and Momol, M. T. 2001. Survival of Ralstonia solanacearum in soil under irrigated rice culture and aquatic weeds. J. Phytopathol. 149:707-711.

30. Pradhanang, P. M., Momol, M. T., Olson, S. M., and Jones, J. B. 2003. Effects of plant essential oils on Ralstonia solanacearum population density and bacterial wilt incidence in tomato. Plant Dis. 87:423-427.

31. Scheie, A. A. A. 1989. Modes of action of currently known chemical anti-plaque agents other than chlorhexidine. J. Dental Res. 68:1609-1616.

32. Scott, J. W., Jones, J. B., and Somodi, G. C. 1995. 'Neptune', a heat-tolerant, bacterial-wilt tolerant tomato. HortScience 30:641-642.

33. Shaaya, E., Ravid, U., Paster, N., Juven, B., Zisman, U., and Pisarev, V. 1991. Fumigant toxicity of essential oils against four major stored-product insects. J. Chem. Ecol. 17:499504.

34. Shapiro, S., and Guggenheim, B. 1995. The action of thymol on oral bacteria. Oral Microbiol. Immunol. 10:241-246.

35. Stavisky, J., Funderburk, J., Brodbeck, B. V., Olson, S. M., and Andersen, P. C. 2002. Population dynamics of Frankliniella spp. and tomato spotted wilt incidence as influenced by cultural management tactics in tomato. J. Econ. Entomol. 95(6):1216-1221.

36. Stead, D. E. 1992. Grouping of plant pathogenic and some other Pseudomonas spp. by using cellular fatty acid profiles. Int. J. Syst. Bacteriol. 42:281-295.

37. U.S. Department of Agriculture. 1976. United States Standards for Grades of Fresh Tomato. U.S. Dep. Agric., Agric. Marketing Serv. pp. 111.

38. Walsh, S. E., Maillard, J.-Y., Russell, A. D., Catrenich, C. E., Charbonneau, D. L., and Bartolo, R. G. 2003. Activity and mechanisms of action of selected biocidal agents on Grampositive and -negative bacteria. J. Appl. Microbiol. 94:240-247.

39. Weissinger, W. R., McWatters, K. H., and Beuchat, L. R. 2001. Evaluation of volatile chemical treatments for lethality to Salmonella on alfalfa seeds and sprouts. J. Food Prot. 64:442-450.

40. Wilson, C. L., Solar, J. M., El Ghaouth, A., and Wisniewski, M. E. 1997. Rapid evaluation of plant extracts and essential oils for antifungal activity against Botrytis cinerea. Plant Dis. 81:204-210. 